\title{
Biocides and Brexit: Hope for the Best - Prepare for the Worst
}

\author{
Hannah Widemann, Eléonore Mullier and Darren Abrahams*
}

The exact effects of Brexit will depend to a large extent on the existence and content of a ratified withdrawal agreement. At the time of writing it is uncertain whether such an agreement can be signed and ratified before the date of withdrawal of the UK from the EU. ${ }^{1}$ Preparation for a UK withdrawal, without such agreement, is therefore underway in both the EU-27 and the UK. One thing is certain: even if an agreement is reached, the UK will eventually lose its status as an EU 'Member State'. This, in itself, has far reaching implications for the biocides sector and companies should act now to mitigate the risk of market disruption.

\section{Introduction}

The UK notified its intention to withdraw from the European Union (EU) under Article 50 Treaty on European Union (TEU) ${ }^{2}$ on 29 March 2017. This means that the UK will leave the EU on 30 March 2019, ०0:00 CET ('Brexit' or 'Withdrawal Date'). ${ }^{3}$ As of that date, the UK will cease being a Member State and become a so-called 'third country'. The consequences of Brexit will depend to a large extent on whether ongoing negotiations, between the remaining 27 EU Member States ('EU-27') and the UK, results in an orderly withdrawal or a hard Brexit.

\section{Orderly Withdrawal}

In an orderly withdrawal scenario the EU-27 and the UK would reach an agreement on the terms and conditions of the UK's withdrawal from the EU, possi- bly with a transition period. ${ }^{4}$ An agreement would also need to be reached on the future relationship between the EU-27 and the UK. A number of scenarios were initially envisaged as possible forms for such a future relationship, including membership in the European Economic Area ('EEA'), various types of free trade agreement and/or a customs union. The majority of these scenarios have already been ruled out due to political redlines or sensitivities. The negotiations between the EU-27 and the UK have thus become focused on a sui generis agreement.

\section{Hard Brexit}

If no agreement is reached and ratified by the Withdrawal Date, '[a]ll Union primary and secondary law ceases to apply to the United Kingdom from 30 March 2019, oo:ooh (CET). ${ }^{5}$ Such a 'hard' or 'no-deal' Brexit would mean that the UK would not only be-
DOI: $10.21552 / \mathrm{icrl} / 2018 / 4 / 4$

* Hannah Widemann, LL.M and Member of the Brussels Bar, is an associate at Steptoe \& Johnson LLP and advises clients on EU regulatory compliance questions in the areas of chemical and product regulations, including biocides, REACH, CLP and plant protection products. For correspondence: <hwidemann@steptoe .com>. Eléonore Mullier is a Member of the Brussels Bar and senior associate at Steptoe \& Johnson LLP and is specialized in EU regulatory law and litigation. She advises clients on regulatory compliance, litigation strategies and product defense in the field of chemical law and product regulations, as well as related support on contracts and negotiations. For correspondence: <emullier@steptoe.com>. Darren Abrahams, is an English barrister, Avocat at the Brussels Bar and partner at Steptoe \& Johnson LLP. He enables clients throughout the chemicals and life sciences supply chain to get and keep their products on the European Union market through strategic advice, advocacy before institutions and agencies, and litigation before EU and national courts and tribunals. For correspondence: <dabrahams@steptoe .com>. The views set forth in this article are the personal views of the authors and do not necessarily reflect those of Steptoe \& Johnson LLP or any of its clients. Nothing herein is intended to constitute legal advice.

1 This article reflects the Brexit texts available to the authors, mentioned herein, as of 23 November 2018.

2 Consolidated version of the Treaty on European Union [2012] OJ C 326, 13-390.

329 March 2019, 11 pm in the United Kingdom.

4 See section II.1, below. The current Draft Withdrawal Agreement in Art 126 foresees a transition period until 31 December 2020.

5 European Commission, 'Notice to Stakeholders' (2017). 
come a third country at this point but would also be treated as one immediately - without further transition. Amongst other consequences, WTO tariffs would apply and there would no longer be mutual recognition of certifications, authorisations or standards for circulation of goods. New trade deals would need to be negotiated. Since EU law would no longer apply within the UK, the UK would be required to promptly enact legislation covering the areas formerly governed by EU law to avoid leaving a vacuum of unregulated areas.

\section{Status of the Negotiations}

Negotiations between the EU-27 and the UK on an agreement setting out transitional arrangements for the withdrawal of the UK from the EU and an outline of the future relationsare underway-but whether they will be completed in good time is still uncertain at the time of writing.

The first phase of the Brexit negotiations started with the European Council - in its 'Article 50' composition, excluding the UK - issuing Guidelines for the withdrawal negotiations ('Guidelines') ${ }^{6}$ and appointing the European Commission ('Commission') as 'Union negotiator'. The Commission's negotiation team, the 'Article 50 task force', is headed by chief negotiator Michel Barnier. The Guidelines set out the priority areas in which 'sufficient progress' had to have been made before advancing to the second phase. These priority areas included EU citizens' rights, $^{8}$ a financial settlement ${ }^{9}$ and stated, with re-

6 European Council, 'Guidelines Following The United Kingdom's Notification Under Article 50 TEU' (29 April 2017) <https://www .consilium.europa.eu/media/21763/29-euco-art50-guidelinesen .pdf $>$ accessed 23 November 2018

7 See para 28 of the Guidelines (n 6), endorsing the arrangements set out in the statement of 27 Heads of State or Government on 15 December 2016. The Informal meeting of the Heads of State or Government of 27 Member States, as well as the Presidents of the European Council and the European Commission Brussels, 15 December 2016 are available at <https://www.consilium.europa .eu/media/24173/15-euco-statement.pdf > accessed 23 November 2018.

8 See Guidelines (n 6) para 8.

9 ibid para 10

10 ibid para 11

11 Joint report from the negotiators of the European Union and the United Kingdom Government on progress during phase 1 of negotiations under Article 50 TEU on the United Kingdom's orderly withdrawal from the European Union of 8 December gard to the issue of the Irish border, that 'flexible and imaginative solutions will be required, including with the aim of avoiding a hard border, while respecting the integrity of the Union legal order. ${ }^{10}$

On 8 December 2017, the Commission published the UK and EU-27's Joint report on phase one progress. ${ }^{11}$ The report found that sufficient progress had been made in key areas and recommended moving to the second phase. This recommendation was endorsed by the European Council (in its Article 50 composition) on 15 December 2017.

During the second phase of the negotiations, on 19 March 2018, the Commission published a first version of the text of the draft Withdrawal Agreement ('March Draft Withdrawal Agreement'). ${ }^{12}$ The March Draft Withdrawal Agreement reflects the political agreement reached between the EU-27 and UK on a number of issues and flags provisions which remained under discussion. It foresees a transitional period - during which ' $[\mathrm{u}$ ]nless otherwise provided in this Agreement, Union law shall be applicable to and in the United Kingdom ${ }^{13}$ - from its entry into force until 31 December 2020. ${ }^{14}$

On 12 July 2018, the UK published a white paper on ' $[\mathrm{t}$ ]he future relationship between the United Kingdom and the European Union' ('the White Paper', also referred to as 'the Chequers Plan') which sets out its preferred way forward in the negotiations. ${ }^{15}$ As regards chemical regulation, it states that the UK is 'seeking participation'16 in the European Chemicals Agency ('ECHA') to ensure that products only go through one approval mechanism (for access to both the EU-27 and UK market) and 'ensuring UK

2017, available at <https://ec.europa.eu/commission/sites/beta -political/files/joint_report.pdf> accessed 23 November 2018.

12 European Commission, Task Force for the Preparation and Conduct of the Negotiations with the United Kingdom under Article 50 TEU, 'Draft Agreement on the withdrawal of the United Kingdom of Great Britain and Northern Ireland from the European Union and the European Atomic Energy Community highlighting the progress made (coloured version) in the negotiation round with the UK' (16-19 March 2018) TF50 ('March Draft Withdrawal Agreement') available at $<$ https://ec.europa.eu/commission/sites/beta-political/ files/draft_agreement_coloured.pdf > accessed 23 November.

13 See Art 122(1) of the March Draft Withdrawal Agreement (n 12).

14 ibid.

15 HM Government, 'The future relationship between the United Kingdom and the European Union' (July 2018) <https://assets .publishing.service.gov.uk/government/uploads/system/uploads/ attachment data/file/725288/The future relationship between _the_United_Kingdom_and_the_European_Union.pdf $>$ accessed 23 November 2018.

16 ibid para 30 
businesses could continue to register chemical substances directly, rather than working through an EUbased representative.. ${ }^{17}$ Moreover, it proposes that the recognition of authorisations, approvals, certifications, and any agency activity completed before the end of the transition period ${ }^{18}$ should be recognized as valid in both the EU-27 and the UK. The White Paper was met by opposition within the UK (triggering the resignation of Brexit Secretary David Davis as well as Foreign Secretary Boris Johnson) as well as from the EU-27. The EU's criticism focused, in particular, on what was considered a 'cherry picking' approach to the EU Single Market's four freedoms (free movement of people, goods, services and capital). For the EU, this approach posed a threat to the integrity of the Single Market, since the UK wished to remain within for goods but not for services.

The October 2018 summit had been envisioned as a key milestone in the negotiations. It had been expected that by this juncture an agreement on the content of a withdrawal agreement would have been reached. However, the summit passed without further progress. This was mostly due to diverging views on the issue of the Irish border. The UK's proposal to use a custom arrangement in order to avoid a hard border in Ireland was considered complex and unworkable. ${ }^{19}$ The UK had initially stated being opposed to an Irish 'backstop' (a measure allowing an open border on the island of Ireland) because it would create a border, in the Irish sea, between Northern Ireland and the rest of the UK. ${ }^{20}$

On 14 November 2018, the UK announced that the Cabinet of the UK Government had formally agreed upon a new version of the draft agreement on the

17 ibid

18 ibid para 31

19 The Economist, 'The unlikely survival of May's Chequers plan for Brexit' The Economist (London, 13 September 2018).

20 Martin Banks, 'No Brexit without backstop, says EU Parliament President' (The Parliament Magazine, 19 October 2019) <https:// www.theparliamentmagazine.eu/articles/news/no-brexit-without -backstop-says-eu-parliament-president $>$ accessed 23 November 2018.

21 European Commission, Task Force for the Preparation and Conduct of the Negotiations with the United Kingdom under Article 50 TEU, 'Draft Agreement on the withdrawal of the United Kingdom of Great Britain and Northern Ireland from the European Union and the European Atomic Energy Community, as agreed at negotiators' level' (14 November 2018) TF50 < https://ec.europa .eu/commission/sites/beta-political/files/draft withdrawal _agreement_0.pdf> accessed 23 November 2018.

22 European Commission, Task Force for the Preparation and Conduct of the Negotiations with the United Kingdom under Article
UK's withdrawal ('Draft Withdrawal Agreement') $)^{21}$ as well as a first outline of the political declaration setting out the framework for the future relationship between EU-27 and UK ${ }^{22}$. A complete 'draft Political declaration setting out the framework for the future relationship between the European Union and the United Kingdom' ('Political Declaration') was published shortly thereafter. ${ }^{23}$

Whilst both documents have been 'agreed at negotiators' level and in principle at political level' they still have to be approved at the government level of the EU-27. ${ }^{24}$ Whilst the EU-27 leaders' endorsement is scheduled for the forthcoming European Council summit of 25 November, their agreement is not guaranteed and some EU-27 leaders have expressed further concerns on the Draft Withdrawal Agreement. ${ }^{25}$ At the time of writing it is still unclear whether the EU-27 leaders will reach a political agreement on the two documents. In any event, there is growing concern as to whether sufficient time remains since- even once there is political agreement on the Draft Withdrawal Agreement - it would still need to be ratified by both the EU and UK before the Withdrawal Date.

In the EU-27, the ratification means consent by the European Parliament and thereafter adoption by the Council (separate approval or ratification by the individual EU-27 Member States would not be required). ${ }^{26}$ The European Parliament would vote by a 'simple majority of the votes cast'. In the Council, Article $238(3)(b)^{27}$ of the Treaty on the Functioning of the European Union ('TFEU') ${ }^{28}$ requires a 'super qualified majority' (ie a higher threshold than the normal qualified majority defined by Article 238(a) of the TFEU) and requires 'at least $72 \%$ of the members of

50 TEU, 'Outline of the political declaration setting out the framework for the future relationship between the European Union and the United Kingdom of Great Britain and Northern Ireland, as agreed at negotiators' level' (14 November 2018) TF50 <https://ec.europa.eu/commission/sites/beta-political/files/ outline_of_the_political_declaration.pdf $>$ accessed 23 November 2018.

23 Council of the European Union, 'Political declaration setting out the framework for the future relationship between the European Union and the United Kingdom' (22 November 2018) XT 21095/18 < https://www.consilium.europa.eu/media/37059/ 20181121-cover-political-declaration.pdf > accessed 23 November 2018 .

24 ibid.

25 For instance, Spain's concern on the status of Gibraltar.

26 See Art 50 (2) and (4) of the TEU.

27 See Art 50(4) of the TEU.

28 (n 2) 47-390 
the Council [ie 20 Member States of the EU- $27^{29}$ ] representing the participating Member States, comprising at least $65 \%$ of the population of these States.'

The UK ratification process will entail, amongst other things, a 'meaningful vote' on the text by the UK Parliament ${ }^{30}$ and additional scrutiny under the Constitutional Reform and Governance Act 2010 ('CRAG'). ${ }^{31}$ The UK would also need to adopt the EU (Withdrawal Agreement) Bill ${ }^{32}$, which would give the withdrawal agreement effect within the UK's domestic legal system. As the time left to conclude and ratify a withdrawal agreement diminishes, the potential for exposure to political pressure grows.

\section{Preparations for a Hard Brexit}

In view of the initially slow progress of the negotiations on a withdrawal agreement and political uncertainty surrounding sufficient time for ratification, both the EU-27 and the UK have initiated contingency planning. They have proposed measures and published Brexit 'no-deal' guidelines. In adopting these guidance documents, both the EU-27 and the UK seem to have taken the view that preparedness for the worst case scenario is crucial in light of the considerable uncertainties which remain. For instance, the UK has stated that 'it's our duty as a responsible government to prepare for all eventualities, including 'no deal" ${ }^{\prime 33}$. Similarly, the EU-27 Guidelines highlight the 'principle that nothing is agreed until everything is agreed.. ${ }^{34}$

29 As per Art 50 (2) and (4) of the TEU, the UK would not participate in the Council vote.

30 Introduced by the UK - EU Withdrawal Act.

31 This would allow both Houses of Parliament to object to it by resolution within 21 days. The CRAG is available $<$ https://www legislation.gov.uk/ukpga/2010/25/contents> accessed 23 November 2018.

32 Formerly the Withdrawal Agreement \& Implementation Bill ('WAIB').

33 Department for Environment Food \& Rural Affairs, 'Guidance Regulating biocidal products if there's no Brexit deal' (12 October 2018) <https://www.gov.uk/government/publications/regulating -biocidal-products-if-theres-no-brexit-deal> accessed 23 November 2018 .

34 (n 6) para 2.

35 European Commission, 'Notice to Stakeholders: Withdrawal of the United Kingdom and EU Rules on Biocidal Products' (23 January 2018) <https://ec.europa.eu/info/sites/info/files/file _import/biocidal-product_en.pdf> accessed 23 November 2018.

\section{EU-27}

The EU-27 started communicating on the expected impacts of Brexit early on, through the publication of stakeholder notices. The different services of the Commission published notices outlining the consequences of the withdrawal of the United Kingdom from the European Union without a formal, ratified agreement (...)' in a range of regulatory areas - including Biocides ${ }^{35}$ and Plant Protection Products ${ }^{36}$. In the area of chemicals regulation, these have been further supplemented with Q\&As by the Commission $^{37}$ and ECHA. ${ }^{38}$ The Q\&As are each considered to be a 'living document' and are regularly updated, as further contingency measures are taken, understanding of Brexit and its likely effects increases, and 'developments unfold'. 39 This was the case again the day before the publication of the Draft Withdrawal Agreement, as the Commission published a communication on contingency actions in priority areas in the event of a hard Brexit. $^{40}$

\section{UK}

The UK only started publishing similar guidance documents - addressing the impacts of Brexit in the UK - in the last months. The Department for Environment, Food \& Rural Affairs ('Defra') published Guidance on regulating biocidal products if there is a hard Brexit, on 12 October 2018 ('UK BPR No Deal Guidance'). It foresees that the UK intends to establish 'an

36 European Commission, 'Notice to Stakeholders: Withdrawal of the United Kingdom and EU Rules on Plant Protection Products' (23 January 2018) <https://ec.europa.eu/info/sites/info/files/file import/plant_protection_products_en.pdf $>$ accessed 23 November 2018 .

37 European Commission, 'Questions and answers related to the United Kingdom's withdrawal from the European Union with regard to the biocides sector' (23 October 2018) < https://ec .europa.eu/info/sites/info/files/qa_biocides.pdf> accessed 23 November 2018.

38 ECHA, 'Brexit Q\&A' <https://echa.europa.eu/advice-to-companies -q-as/general> accessed 23 November 2018.

39 ECHA, 'How will the UK withdrawal affect you?' <https://echa .europa.eu/uk-withdrawal-from-the-eu> accessed 23 November 2018.

40 European Commission, 'Brexit: European Commission intensifies preparedness work and outlines contingency action plan in the event of a no deal scenario with the UK' (2018) <http://europa eu/rapid/press-release_IP-18-6403_en.htm> accessed 23 November 2018. 
independent standalone biocidal products regime' ('UK BPR'). ${ }^{41}$

Whilst the specificities of that future UK BPR regime are still uncertain, the document sets out that both existing active substance approvals and biocidal product authorisations would be 'grandfathered' into the UK BPR and remain valid in the UK until their normal expiry date. ${ }^{42}$

The UK BPR No Deal Guidance foresees the establishment of a 'UK Article 95 list' which would include all entities that are featured on the EU Article 95 list at the time of the Withdrawal Date. The entries of the EU Article 95 List would thus, at least at the outset, automatically be grandfathered into the UK equivalent list. However, in order to remain on the UK list, the entities would need to submit supporting information to the UK Health and Safety Executive ('the HSE'), 'for example, an active substance dossier or a letter of access'. ${ }^{43}$ The UK BPR No Deal Guidance suggests that the administrative burden of such submissions would be limited, since they would relate to 'supporting data or other information that has previously been submitted to ECHA'. ${ }^{44}$ This fails to address two facts which could impede the straightforward resubmission of data previously submitted under the EU BPR under the new UK BPR. First, data (access) rights expressly granted for the purpose of the EU BPR would in principle not allow the submission of such data in the framework of a different legal regime, ie the UK BPR. Second, the obligation to share data on vertebrate animals and the principle of fair, transparent and non-discriminatory cost sharing only apply to operators subject to the EU BPR.

The same Guidance provides that under the UK BPR, authorisation holders would need to be established within the UK. In practice, this would lead to a duplication of authorisation holders in order to secure market access for both the UK and EU-27 mar-

\footnotetext{
41 (n 33).

42 (n 33) 4, '[a]ctive substance approvals would also remain valid until their normal expiry date' and likewise that 'a biocidal product authorisation that is valid in the UK on exit day, (...) would remain valid in the UK after exit day until its normal expiry date'.

43 (n 33).

44 ibid.

45 Regulation (EU) No 528/2012 of the European Parliament and of the Council of 22 May 2012 concerning the making available on the market and use of biocidal products [2012] OJ L 167, 1-123, as amended.

46 See Annex VII, para 6 of the Draft Withdrawal Agreement.
}

kets. Whilst a phase-in period to comply with these requirements is envisaged, its duration is not yet established.

Defra has further committed that, for biocidal product authorisation applications that are pending before the HSE at the Withdrawal Date, the 'HSE would, where possible, continue to process this to grant a national authorisation' (in the UK). On the other hand, for applications pending on the Withdrawal Date before other EU-27 competent authorities, it would be necessary to resubmit an application for a national authorisation in the UK.

\section{Direct Impacts under the EU BPR}

Despite the recent progress on the content of the Draft Withdrawal Agreement, at the time of writing it is still difficult to predict whether a withdrawal agreement will be signed and ratified in time. Nonetheless, a number of impacts are unavoidable, regardless of whether negotiations succeed or fail. The UK will cease to be a Member State of the EU and will become a third country. Even if a withdrawal agreement was to provide that EU law continues to apply to the UK, this would only be for a transitional period. The UK would no longer form part of the EU block.

\section{General}

The fact that the UK becomes a third country has important implications for the application of the EU's legislation on biocides, the Biocidal Products Regulation ('BPR'). ${ }^{45}$ These implications derive, in essence, from the fact (i) that the UK will no longer be a 'Member State'; and (ii) that consequently companies established in the UK will no longer be 'established in the Union'.

The Draft Withdrawal Agreement touches upon some of those impacts in two provisions. First, Article 128(6) provides that 'the United Kingdom shall not act as leading authority for risk assessments, examinations, approvals and authorisations at the level of the Union or of Member States acting jointly as referred to in [the $\mathrm{BPR}^{46}$ ]'during the transition period. This would mean that even in the event of a transitional application of EU law to the UK, after the Withdrawal Date, UK competent authorities could no longer act as evaluating Competent Authority 
('eCA') or reference Member State for BPR processes. Second, the Draft Withdrawal Agreement requires the UK to 'transfer without delay to the competent authority of a Member State (...) all relevant files or documents in relation to assessments, approvals and authorisations ongoing on the day before the date of entry into force of this Agreement and led by a United Kingdom competent authority in accordance with Regulation (EU) No 528/2012 (...). ${ }^{47}$

\section{Direct Impacts for Active Substances}

A biocidal product containing active substances that are still under review or have already been approved cannot be made available on the EU-27 market unless either the substance supplier or the product supplier is included in ECHA's Article 95 list for the product-type ('PT') to which the product belongs. ${ }^{48}$ The BPR defines both a substance supplier and a product supplier as '[a] person established within the Union $(\text {... })^{49}$ After the Withdrawal Date, entities established in the UK will no longer be an entity 'established within the EU', ie established within one of the re maining EU-27 Member States, and an Article 95 list entry relying on a UK-established entity (either as product or substance supplier or as EU representative of a non-EU substance or product supplier) will thus no longer be able to ensure market access.

To ensure continued market access where the product supplier or substance supplier on the EU Article 95 list is established in the UK, it is necessary to appoint a representative established within the EU-27 (or the EEA countries or Switzerland). This is done by submitting a 'request for correction of entries on the Article 95 list' to ECHA. ${ }^{50}$ Such transfers should be made without delay in order to avoid interruption of market access if, on the Withdrawal Date, the UK-established substance or product supplier has not yet been replaced by an EU-27 substance or product supplier.

\section{Active Substances under the Review Programme}

The evaluation of existing active substance/PT combinations is governed by the Review Programme Regulation $^{51}$ which attributes this evaluation to the competent authority of a Member State of the EU (the
'eCA'). A reallocation of evaluations undertaken by the UK eCA to the authorities of the EU-27 is therefore necessary in view of Brexit, since the UK will no longer be an EU Member State. This is irrespective of whether agreement on the Draft Withdrawal Agreement is reached since, as explained above, the current text of the Draft Withdrawal Agreement foresees that the UK may no longer act as an eCA even during a transition period. ${ }^{52}$

The Commission has published a Draft regulation amending the Review Programme ('Draft Review Programme Amendment' $)^{53}$ which foresees the transfer of 18 active substance dossiers that were scheduled for evaluation by the UK HSE to eCAs of the EU-27. The dossiers would be transferred to the Czech Republic (4), Germany (3), Sweden (2), France (2), Italy (2), Poland (2), Austria (1), Hungary (1) and Switzerland (1). It goes without saying that such reallocations will increase the workload of those EU-27 CAs and it is feared that the reallocation will further delay an already chronically delayed Review Programme. The Draft Review Programme Amendment foresees that the EU-27 eCAs will have to submit their conclusions and assessment reports by 31 December

47 Art 44 of the Draft Withdrawal Agreement. These provisions appear to deviate from the provision of Art 7 of the Draft Withdrawal Agreement according to which 'For the purposes of this Agreement, all references to Member States and competent authorities of Member States in provisions of Union law made applicable by this Agreement shall be understood as including the United Kingdom and its competent authorities'.

48 Art 95(2) of the BPR.

49 Art 95(1) and (2) of the BPR. Substance supplier is defined as 'a person established within the Union who manufactures or imports a relevant substance'. Product supplier is defined as 'a person established within the Union (...) who manufactures or makes available on the market a biocidal product'.

$50 \mathrm{ECHA}$, 'Request for correction of entries on the Art.95 list' $<$ https://echa.europa.eu/documents/10162/17169198/supporting document art95list_en.doc/d1b69637-9b54-44fe-9880 -8ee490ebc44d> accessed 23 November 2018.

51 Commission Delegated Regulation (EU) No 1062/2014 of 4 August 2014 on the work programme for the systematic examination of all existing active substances contained in biocidal products referred to in Regulation (EU) No 528/2012 of the European Parliament and of the Council [2014] OJ L 294, 1-34.

52 Art 128(6) of the Draft Withdrawal Agreement

53 Draft delegated regulation Ares(2018)4534493 'Commission Delegated Regulation (EU) amending Delegated Regulation (EU) No 1062/2014 as regards certain active substances/product-type combinations for which the competent authority of the United Kingdom has been designated as the evaluating competent authority; Annex Ares(2018)4534493/1 'Annex to the Commission Delegated Regulation (EU) amending Delegated Regulation (EU) No 1062/2014 as regards certain active substances/producttype combinations for which the competent authority of the United Kingdom has been designated as the evaluating competent authority. 
2020 (but later if the initial date for the UK HSE to do so was later than 31 December 2020). ${ }^{54}$

The Draft Review Programme Amendment is expected to be adopted during the first quarter of 2019, after undergoing scrutiny by the Council and the European Parliament. ${ }^{55}$ It would allow the new, EU-27 eCAs to request fees for their evaluations ' $n$ ] otwithstanding the stage of evaluation of the application, ${ }^{56}$, ie even if the evaluation by the UK HSE was nearly completed. Applicants would be informed by 30 April 2019, at the latest, of the required fees. ${ }^{57}$ The new eCA would reject applications where those fees are not paid. ${ }^{58}$

One might have hoped that these new fees would be set by reference to the proportionality principle, given that substantial fees will have already been paid to the HSE. Regrettably, there is nothing in the current text of the Draft Review Programme Amendment to prevent a new eCA from requesting the full fee payment for its evaluation. National fees have traditionally been an area where it was thought that the subsidiarity principle required deference to member state choices. This may be a situation where that approach is hard to justify, given the double payments which could result.

Similar reallocations have been implemented in other areas of EU chemical regulation, such as for the evaluation of substances under the REACH Regulation. In the March 2018 update to the Community rolling action plan ('CoRAP'), covering the years 2018, 2019 and 2020, ${ }^{59}$ substances which were initially

\footnotetext{
54 The new eCAs may submit the conclusions and assessments reports later if that is foreseen in the timeline of the Review Programme under Art 6(3)b and Annex III.

55 The Draft Review Programme is available at <https://webgate.ec .europa.eu/regdel/\#/delegatedActs/1080> accessed 23 November 2018.

56 ibid recital 5 .

57 ibid Art 1.

58 ibid.

59 ECHA, 'Community rolling action plan update covering years 2018, 2019 and 2020, 20 March 2018' <https://echa.europa.eu/ documents/10162/9801478/corap_update_2018-2020_en.pdf/ 85e5f709-da61-8b06-855c-79302dc17c70 > accessed 23 November 2018.

60 (n 38)

61 ibid.

62 (n 33) Art 3(1)(p): 'authorisation holder' means the person established within the Union who is responsible for the placing on the market of a biocidal product in a particular Member State or in the Union and specified in the authorization'.

63 (n 5) 2
}

scheduled for evaluation by the UK HSE have been assigned to the competent authorities of other, EU-27 Member States.

\section{Renewal Applications and New Approval Applications}

The UK HSE will also no longer be able to act as evaluating authority for active substance renewal applications. Under the BPR it is not necessary to have recourse to the same evaluating authority for the renewal process. Under Article 13(3) of the BPR it is possible to change the eCA at the renewal stage so that other EU-27 authorities could take over the assessment of the renewal application. Likewise, for new applications for active substance approvals, the UK HSE can no longer act as evaluating authority and an EU-27 authority should take charge of the evaluation.

In both instances, it must be borne in mind that EU-27 eCA capacity will become (further) reduced as a result of Brexit, and applicants should proactively seek out eCAs which would be willing to take on new evaluations. The eCA's acceptance might be facilitated if that eCA already has experience with similar substances or with the specific PT.

Applications for renewal or for new approvals do not necessarily have to be submitted by applicants established in the EU-27. A third country (ie UK) entity may very well submit such applications since 'applicants for the approval of an active substance or Annex I inclusion are not 'holders'/'owners' of an approval and do not need to be established in the EU'60 and it will still be possible for third country companies to access R4BP for a number of measures, such as 'active substance approval, notifications and submissions. ${ }^{61}$

\section{Direct Impacts for Biocidal Products}

One of the unavoidable effects of Brexit under the BPR concerns authorisation holders. Article 3(1)(p) of the BPR provides that holders of biocidal product authorisations must be established within the EU. ${ }^{62}$ After the Withdrawal Date, this would exclude the UK so that, at the latest by that day, authorisation holders under the BPR must be established in the EU-27 (or EEA countries or Switzerland) ${ }^{63}$ In order to en- 
sure continued market access in the EU, the role of authorisation holder needs to be transferred to an EU-27 (or EEA, or Switzerland) based entity. The transfer is done by using the procedure of an administrative change requiring prior notification under Commission Implementing Regulation (EU) No $354 / 2013$ on changes of biocidal products. ${ }^{64}$ It is important to bear in mind that processing this change requires time (Member States have 30 days to disagree with a proposed change ${ }^{65}$ ) and the payment of fees. In view of the expected high workload of both EU-27 Member States and ECHA before the Withdrawal Date, we recommend notifying the change of authorisation holders as soon as possible.

For applications for the authorisation of biocidal products, renewal or mutual recognition the effects of Brexit will depend on the likelihood of completion of the authorisation process before the Withdrawal Date and the type of authorisation. New applications for authorisation under the BPR should no longer be submitted to the HSE as there is insufficient time for the HSE to complete the process before the Withdrawal Date. For pending applications where the UK HSE acts as eCA or reference Member State for mutual recognition, the transfer of the application will be necessary in cases where the UK would not finalise its assessment before the Withdrawal Date.

Whilst the reallocation of pending active substances dossiers to EU-27 eCAs is being prepared per the Draft Review Programme Amendment, as explained above, no such transfer by legal instrument is foreseen for biocidal product authorisations. The technical seminars of the EU-27, focussed on finding eCA/reference Member State solutions, have discussed how to address the transfer of pending applications for biocidal product authorisations, renewals and mutual recognition when unlikely to be completed by the Withdrawal Date. Whilst some progress has been made, there remain a number of 'orphan cases' of biocidal product authorisation applications for which no new EU-27 authority has been found, as yet. ECHA will contact the applicants of these orphan applications and, it is expected, urge them to seek out an EU-27 competent authority willing to take on their case. If the applications are not transferred on time, a second application would have to be submitted before 29 March 2019, according to the Commission. ${ }^{66}$

The impact of Brexit on the validity of granted biocidal product authorisations must also be considered.
The Q\&As published by the Commission and ECHA indicate that (i) authorisations granted by the EU-27 before the Withdrawal Date and (ii) mutual recognition granted based on an authorisation delivered by the UK before the Withdrawal Date will remain valid. After the Withdrawal Date, however, authorisations granted by the UK will no longer be able to form the basis for mutual recognition under the BPR. The UK will no longer be able to act as competent authority for applications for changes or renewal of biocidal product authorisations. Such applications can (and should) be submitted to an EU-27 authority, together with confirmation that the new EU-27 authority agrees to take on their role. We also recommend seeking out an EU-27 eCA proactively, given the imminent workload constraints.

\section{Direct Impacts on Contractual Arrangements}

Brexit will also impact the contractual arrangements in place for to the sale, supply or sharing of data on biocidal active substances and products. This concerns in particular the following provisions:

- Geographic scope: Agreements are often limited in geographic scope to the 'European Union'. Unless the definition of 'European Union' in the contract would explicitly include Member States leaving the EU during the validity of the agreement, this would mean that as of the Withdrawal Date the territory of the UK will be excluded from the scope of the agreement.

- Material Scope: agreements (eg data sharing agreements) are often limited in scope and purpose. For instance, agreements might provide that the rights to access data are granted solely 'for purposes of compliance with the BPR'. The data rights acquired under such agreement would hence exclude submission of the data under other regulatory regimes, which after the Withdrawal Date would mean they could not be used for the UK BPR.

64 See point 3 in s 1 of Title I in the Annex to Commission Implementing Regulation (EU) No 354/2013 on changes of biocidal products.

65 Art 6 of Commission Implementing Regulation (EU) No 354/2013 on changes of biocidal products.

66 Commission's presentation at ECHA Biocides Stakeholder Day, 24 October 2018. 
- Applicable Law \& Competent Jurisdiction: agreements may also provide that they are governed by UK law (often the laws of England \& Wales) or that any dispute under the agreement has to be brought before UK courts. Whilst the UK courts have often been used in international matters, it might be considered preferable to entrust issues under EU law to courts which, unlike the UK courts, are still subject to EU law.

A Brexit preparedness strategy should therefore entail reviewing any existing agreements to avoid the potentially negative effects of Brexit. These aspects should certainly also be taken into account when concluding new agreements. Parties may decide to include a clause on Brexit (whether in existing agreements or new agreements), setting out the rights and obligations of both parties in different Brexit scenarios (hard Brexit or orderly withdrawal). This is particularly relevant since Brexit might not be considered a force majeure in many jurisdictions - since it was (at least to a certain extent) foreseeable. Doing so is one of the only ways to increase legal certainty in conditions which are highly uncertain and avoid lengthy discussions as to the impact of Brexit on contractual obligations.

\section{Indirect Impacts}

\section{1. $\mathrm{REACH}$}

Impacts of Brexit on the REACH Regulation ${ }^{67}$ must also be considered as they affect non-active substances (or 'co-formulants') contained in the biocidal product. These co-formulants need to be registered under the REACH Regulation before being placed on the EU market, ie before being imported or manufac-

67 Regulation (EC) No 1907/2006 of the European Parliament and of the Council of 18 December 2006 concerning the Registration, Evaluation, Authorisation and Restriction of Chemicals (REACH), establishing a European Chemicals Agency, amending Directive 1999/45/EC and repealing Council Regulation (EEC) No 793/93 and Commission Regulation (EC) No 1488/94 as well as Council Directive 76/769/EEC and Commission Directives 91/155/EEC 93/67/EEC, 93/105/EC and 2000/21/EC [2006] OJ L 396, 1-849.

68 Art 3(9) of the REACH Regulation.

69 (n 38)

70 Art 3(9) of the REACH Regulation.

71 Art 3(11) of the REACH Regulation.

72 Art 8(1) of the REACH Regulation. tured. The fact that, after the Withdrawal Date, the UK will no longer constitute part of the EU has implications on a number of actors under REACH who have (registration) obligations and are required to be established in the EU. Only some of these key impacts are described here.

First, the REACH Regulation defines 'manufacturer' as any natural or legal person established within the EU. ${ }^{68}$ After the Withdrawal Date, manufacturers of co-formulants established in the UK would no longer meet this definition and would become a 'nonEU manufacturer'. This means that, unless the UK manufacturer appoints an only representative, under Article 8 of REACH, its downstream users could be considered importers (on whom the registration obligation would fall). The REACH Regulation also defines an 'importer' as an entity established in the EU. After the Withdrawal Date, imports of co-formulants into the UK will no longer constitute imports in the meaning of REACH. The role of importer might thus fall on a distributor or downstream user established in the EU who places the co-formulant on the EU-27 market. Companies that have UK established manufacturers or importers in their supply chain should therefore carefully review the supply chain and registration obligations.

Moreover, the REACH registrations of UK-based entities will be considered 'non-existent' after the Withdrawal Date. ${ }^{69}$ This is because a registrant is defined under Article 3(7) of the REACH Regulation as 'the manufacturer or the importer of a substance', which - as set out above - are defined as 'any natural or legal person established within the Community' that manufactures ${ }^{70}$ or is responsible for import. ${ }^{71}$ Similarly, only representatives established in the UK will not be able to exercise that role after Brexit, since the REACH Regulation requires an only representative to be established in the EU. ${ }^{72}$

Another key aspect with regard to the REACH Regulation concerns data sharing. The obligation for data sharing is clearly limited to the purpose of registration of chemicals under the REACH. For instance, Article 10(a) of the REACH Regulation provides: '(...) the registrant shall be in legitimate possession of or have permission to refer to the full study report summarized under (vi) and (vii) for the purpose of registration'. Even though ECHA encourages data owners to share data across different regulatory areas, there is no obligation to do so under REACH, ie there is no obligation to grant access to data or rights to refer for 
the purpose of registering a substance under other regulatory regimes, including a potential future 'UKREACH'. The same issue applies as regards mandatory data sharing under the BPR.

\section{Other Indirect Impacts}

Brexit will have a number of other effects which will have an impact on chemicals and biocides, in particular. Whilst a complete description of these effects exceeds the scope of this article, aspects such as such as the role of customs (and of the PIC Regulation) once the UK becomes a third country must be considered. The role of the Court of Justice (and the interpretative value of its case-law) as well as the availability of remedies before it will be affected. Brexit is also expected to put an end to the active role of the UK in processes and bodies under the BPR, such as the Biocidal Product Committee and Standing Committee for Biocidal Products, even though the Political Declaration foresees that the EU-27 and the UK will 'explore the possibility of cooperation of United Kingdom authorities with Union agencies such as (...) ECHA'.

\section{Conclusion and Key Messages}

With just a couple of months to go before the Withdrawal Date, a lot of uncertainty remains as to whether there will be an agreement on and ratification of the Draft Withdrawal Agreement between the EU-27 and the UK. Whilst the biocidal sector may still hope for the best, it is without doubt time to pre- pare for the worst. The fact that the UK will become a third country entails legal consequences which can already be identified. Companies can no longer afford to adopt a 'wait and see' approach and need to take action now to secure continued market access and minimise disruption after the Withdrawal Date.

A Brexit preparedness strategy should include:

- Notifying the change of entities established in the UK which are no longer able to exercise their regulatory role (under the BPR or REACH) after Brexit. For the BPR this concerns, in particular, entities listed as product or substance suppliers on the EU Article 95 list and biocidal product authorisation holders. Under the REACH Regulation, this would impact, in particular, the roles of registrant and only representative.

- Ensuring that pending and future applications are taken over by competent authorities of the EU-27 and seeking them out proactively where necessary, bearing in mind that their capacity will be placed under additional pressure and that delays are to be expected.

- Negotiating or re-negotiating contractual agreements in order to ensure that Brexit would not have any unwanted or unforeseen effects on the applicability or scope of the agreements.

- Finally, monitoring (i) the progress of the negotiations and in particular the likelihood of a ratification of a withdrawal agreement before the Withdrawal Date; and (ii) the changing and evolving guidance and Q\&As. For entities seeking to place biocidal active substances or products on the UK market, it will also be crucial to follow the No-deal preparedness actions of the UK government. 